\title{
РОЛЬ НАУКОВО-ДОСЛІДНОЇ РОБОТИ СТУДЕНТА У ФОРМУВАННІ МАЙБУТНЬОГО ФАХІВЦЯ
}

\author{
О.І. Готюр ${ }^{1}$, Р.В. Деніна ${ }^{1}$, Д.А. Волинський ${ }^{1}$, О.І. Кочержат ${ }^{2}$ \\ Івано-Франківський національний медичний університет, \\ ${ }^{1}$ кафедра внутрішньої медицини №2 та медсестринства, \\ ${ }^{2}$ кафедра внутрішньої медицини стоматологічного факультету \\ імені професора М.М. Бережницького, \\ м. Івано-Франківськ, Украӥна, \\ ORCID ID: 0000-0001-9687-0112, \\ ORCID ID: 0000-0001-8196-7130, \\ ORCID ID: 0000-0003-4849-8197, \\ ORCID ID: 0000-0003-4568-586X, \\ e-mail:Oksanahotiur@gmail.com
}

Резюме. Науково-дослідна робота студентів (НДР) є невід’ємною складовою наукової діяльності кожного університету України і першим етапом у підготовці наукових кадрів, що зазвичай реалізується на кафедрах (студентські наукові гуртки) і в наукових структурних підрозділах університету (студентське наукове товариство) або на території лікувальних закладів.

Основними завданнями науково-дослідної роботи студентів Івано-Франківського національного медичного університету є: залучення талановитої молоді до наукових досліджень, організація участі студентів у конкурсах студентських наукових робіт, студентських наукових конференціях, олімпіадах. Наукова робота студентів ІФНМУ здійснюється за загальновідомою схемою наукового аналізу. Керівництво НДР студентів здійснюють науково-педагогічні працівники університету. Їхнім основним завданням є допомога студентові в процесі опанування основ наукового пошуку, наданні консультацій та здійсненні контролю за виконанням роботи на всіх їі стадіях. У ході НДР керівник допомагає обрати тему, сформулювати мету і завдання, рекомендує найважливішу літературу та джерела з проблематики роботи, оцінює зміст тексту у його окремих складових та у цілому, рекомендує внесення правок і доопрацювання певних частин роботи.

Система науково-дослідної роботи є важливою складовою професійної підготовки майбутнього фахівця. Науково-дослідна робота повинна бути спрямована на формування особистості майбутнього медика, який, використовуючи набуті у вищій школі навики, а саме: уміння планувати будь-який вид роботи, уміння застосувати цей навик у певних умовах, організаційні, мотиваційні, комунікативні, пізнавальні уміння, тобто підвищить свою конкурентоспроможність на ринку праці.

Ключові слова: науково-дослідна робота, науковий гурток.

Вступ. Важливим етапом у формуванні майбутнього спеціаліста $є$ самостійна робота студента, зокрема, залучення найкращих студентів до науководослідної роботи (НДР).

Традиційно вважається, що НДР студентів це система методів, засобів і заходів для засвоєння студентами в процесі навчання різних етапів науковоінноваційного циклу, що включає фундаментальні й прикладні дослідження. НДР є одним із найважливіших засобів ефективної підготовки кваліфікованих фахівців через оволодіння основами професійної творчої діяльності, методами, прийомами і навичками виконання науково-дослідних робіт, розвитку креативності, самостійності $[1,2]$.

Як показують дослідження провідних учених, реалізована в комплексі науково-дослідна діяльність студентів забезпечує вирішення таких основних завдань:

1. Формування наукового світогляду, оволодіння методологією і методами наукового дослідження.
2. Розвиток творчого мислення та індивідуальних здібностей студентів у вирішенні практичних завдань.

3. Прищеплення студентам навичок самостійної науково-дослідницької діяльності.

4. Розвиток ініціатив та здатності застосовувати теоретичні знання у своїй практичній роботі; залучення здібних студентів до глибшого вивчення наукових проблем, які мають важливе значення в науці і практиці.

5. Необхідність постійного вдосконалення своїх знань та умінь.

6. Розширення теоретичного кругозору та наукової ерудиції майбутнього фахівця.

7. Створення та розвиток наукових шкіл, наукових гуртків, виховання у стінах вищого навчального закладу молодих вчених та дослідників.

Крім того, НДР дозволяє найбільш повно виявити індивідуальність, творчі здібності, готовність до самореалізації особистості студентів. Важливо зазначити, що сам процес дослідження $\epsilon$ суто 
індивідуальним і являє собою цінність як в освітньому, так і в особистісному сенсі [3].

Як відомо, поняття "науково-дослідна діяльність студентів” включає в себе два взаємопов'язаних елементи: навчання студентів основам дослідницької діяльності, організації та методики наукової роботи яку студенти здійснюють під керівництвом професорів, доцентів, асистентів, викладачів.

Перша складова реалізується через залучення усіх студентів у навчально-дослідницьку діяльність, яка поступово трансформується у науково-дослідну. Така робота пов'язана з формуванням навичок роботи 3 науковою літературою, оволодінням знаннями щодо наукової організації праці, підготовкою наукових рефератів, статей, виступів на практичних заняттях, наукових гуртках.

Підготовка будь-якого дослідження здійснюється через низку етапів. На кожному епапі студент працює самостійно, однак важливе місце під час виконання студентських НДР займає науковий керівник. Основне завдання якого полягає у тому, що він повинен допомогти студентові опанувати основи наукового пошуку, надати консультації і провести контроль за виконанням роботи на всіх епапах (обрати тему, сформулювати мету і завдання, рекомендувати важливу літературу, оцінити зміст тексту у цілому, внести правки і допомогти в доопрацюванні роботи.

студента є:

Важливим у співпраці наукового керівника та - формування наукового світогляду, оволодіння методологією, тобто принципами побудови, засобами та формами наукового пізнання;

- надання допомоги студентам у оволодінні спеціальністю, що у подальшому призведе до досягнення високого рівня професіоналізму;

- розвиток творчого мислення та індивідуальних здібностей у вирішенні різної складності практичних завдань;

- - прищеплення студентам навичок самостійного аналітичного мислення;

- розвиток здатності застосувати здобуті теоретичні знання у своїй практичній роботі;

- підвищення конкурентоспроможності на ринку праці.

Наукова робота студентів-гуртківців ІФНМУ здійснюється за загальновідомою схемою наукового аналізу:

- вибір та обгрунтування теми дослідження;

- обгрунтування об'єкта і предмета дослідження;

- постановка мети і завдань дослідження;

- робота з науковою літературою;

- проведення досліджень (робота з хворими, аналіз історій хвороби, тощо);

- аналіз та узагальнення отриманих результатів;

- оцінка практичного значення дослідження;

- оцінка достовірності та наукової новизни дослідження;

- впровадження результатів наукового дослідження; - формування тексту наукової роботи.

Керівництво НДР студентів здійснюють науково-педагогічні працівники університету. НДР студентів складається 3 науково-дослідної роботи, яка $є$ складовою частиною навчального процесу і науководослідної роботи, що виконується в позанавчальний час. Форми НДР, які можуть бути передбачені навчальними планами кафедри, або ж бути виконані за ініціативою студента (цікаві клінічні випадки, рідкісні синдроми тощо), включають в себе: вивчення лекційного курсу, який має на меті формувати у студентів практичні навички застосування загальнотеоретичних знань, допомогти провести перше наукове дослідження на належному рівні, засвоїти перші дослідницькі уміння та навички; виконання завдань, лабораторних, та практичних робіт; написання рефератів за науковою тематикою, в яких містяться елементи дослідницької роботи; виконання конкретних завдань науково-дослідного характеру під час виробничої або навчальної практики.

Система НДР як складова професійної підготовки повинна бути спрямована на формування особистості майбутнього лікаря, який, використовуючи набуті у вищій школі навики та уміння, а саме: уміння планувати будь-який вид роботи, уміння застосувати цей навик у певних умовах, організаційні, мотиваційні, комунікативні, пізнавальні уміння, тобто підвищить свою конкурентоспроможність на ринку праці.

На підставі виконаних наукових досліджень провадиться підготовка матеріалів до публікації в студентському збірнику наукових праць, а також цілеспрямована робота 3 підготовки студентівгуртківців до виступів на щорічних університетських наукових конференціях. Представляючи свої науково-дослідні роботи, гуртківці демонструють навички ораторського мистецтва, вміння самостійно міркувати, висловлювати своє бачення проблеми та шляхи її вирішення, відповідати на поставлені запитання, приймати участь у дискусії. За активну участь у роботі студентського наукового гуртка і за зайняті призові місця студенти-гуртківці отримують преміальні бали, які долучаються до загальної суми балів за Модуль.

Науково-практичні конференції, містять у собі не тільки теоретичні наукові доповіді, а й обговорення шляхів вирішення практичних завдань. Дуже часто вони проводяться спільно з лікувальними закладами (на базі лікарень, поліклінік, санаторіїв), 3 якими ВНЗ співпрацює. Наприклад, науковопрактичні конференції можуть проводитись за результатами роботи певного напрямку у клінічній медицині, що в свою чергу сприяє установленню тісних зв'язків між вищим навчальним закладом i лікувальною установою. Такі конференції допомагають студентам вчитися клінічно мислити і застосовувати вивчену теорію на практиці. Важливою ознакою такої науково-практичної конференції $є$ злагодженість організації, так, щоб участь була однаково корисною та цікавою для студентів і працівників лікувально-профілактичних закладів.

Висновки. Отже, науково-дослідна робота студентів у медичному університеті $є$ невід'ємною складовою освітньої діяльності і здійснюється 3 метою інтеграції наукової та навчальної роботи в системі вищої освіти і є невід'ємною складовою професійної 
компетентності і конкурентоспроможності майбутнього випускника на ринку праці.

\section{References:}

1. Sydorenko VK, Dmytrenko PV. Prohramy vyshchykh pedahohichnykh zakladiv osvity: Osnovy naukovykh doslidzhen / Ukl. K., 2000. P.15.

2. Sydorenko VK, Dmytrenko PV. Osnovy naukovykh doslidzhen. Navchalnyi posibnyk dlia vyshchykh pedahohichnykh zakladiv osvity. K.: RNNTs "DINIT", 2013. P.260.

3. Sopivnyk I. Naukovo-doslidnytska robota studentiv yak skladova yikhnoi profesiinoi kompetentnosti [Elektronnyi resurs]. 2018. Available from: http://dlib.eastview.com/browse/doc19619143

4. Struktura naukovo-doslidnytskoi diialnosti studentiv u vyshchomu navchalnomu zakladi [Elektronnyi resurs]. 2019. Available from: http://revolution.allbest.ru/pedagogics/ 00030363.html. 5. Voloshchuk NI, Denysiuk OM. Indyvidualna robota v studentskomu naukovomu hurtku kafedry farmakolohii yak faktor formuvannia profesiinykh kompetentsii. Bukovynskyi medychnyi visnyk. 2014; 4(72):257-259.

\section{УДК $378.147+614.253 .4$}

\section{РОЛЬ НАУЧНО-ИССЛЕДОВАТЕЛЬСКОЙ РАБОТЫ СТУДЕНТА В ФОРМИРОВАНИИ БУДУЩЕГО СПЕЦИАЛИСТА}

О.И. Готюр ${ }^{1}$, Р.В. Денина ${ }^{1}$, Д.А. Волынский ${ }^{1}$, О.И. Кочержат ${ }^{2}$

Ивано-Франковский национальный медицинский университет,

${ }^{1}$ кафедра внутренней медищины №2 и медсестринства,

${ }^{2}$ кафедра внутренней медицины стоматологического факультета имени профессора Н.Н. Бережницкого,

2. Ивано-Франковск, Украина,

ORCID ID: 0000-0001-9687-0112,

ORCID ID: 0000-0001-8196-7130,

ORCID ID: 0000-0003-4849-8197,

ORCID ID: 0000-0003-4568-586X,

e-mail:Oksanahotiur@gmail.com

Резюме. Научно-исследовательская работа студентов (НИР) является неотъемлемой составляющей научной деятельности каждого университета Украины и первым этапом в подготовке научных кадров, обычно реализуется на кафедрах (студенческие научные кружки) и в научных структурных подразделениях университета (студенческое научное общество).

Основными задачами научноисследовательской работы студентов ИваноФранковского национального медицинского университета являются: привлечение талантливой молодежи к научным исследованиям, организация участия студентов в конкурсах студенческих научных работ, студенческих научных конференциях, олимпиадах. Научная работа студентов ИФНМУ осуществляется по общеизвестной схеме научного анализа. Руководство НИР студентов осуществляют научнопедагогические работники университета. Их основной задачей является помощь студенту в процессе постижения основ научного поиска, предоставлении консультаций и осуществлении контроля над выполнением работы на всех ее стадиях. В ходе НИР руководитель помогает выбрать тему, сформулировать цели и задачи, рекомендует важнейшую литературу и источники по проблематике работы, оценивает содержание текста в его отдельных составляющих и в целом, рекомендует внесения поправок и доработки определенных частей работы.

Система научно-исследовательской работы является важной составляющей профессиональной подготовки будущего специалиста. Она должна быть направлена на формирование личности медицинского работника, который, используя приобретенные в высшей школе проектировочные (умение планировать любой вид работы), адаптационные (умение применить данный план в конкретных условиях), организационные, мотивационные, коммуникативные, познавательные способности, таким образом повысит свою конкурентоспособность на рынке труда.

Ключевые слова: научно-исследовательская работа, научный кружок.

\section{UDC $378.147+614.253 .4$ \\ THE ROLE OF THE STUDENT'S RESEARCH WORK IN THE FORMATION OF A FUTURE PROFESSIONAL}

O.I. Gotyur ${ }^{1}$, R.V. Denina ${ }^{1}$, D.A. Volynskyi ${ }^{1}$, O.I. Kocharzhat ${ }^{2}$

Ivano-Frankivsk National Medical University, ${ }^{1}$ Department of Internal Medicine №2 and Nursing,

${ }^{2}$ Department of Internal Medicine of the Dental Faculty named after Professor M.M. Berezhnitsky,

Ivano-Frankivsk, Ukraine,

ORCID ID: 0000-0001-9687-0112,

ORCID ID: 0000-0001-8196-7130,

ORCID ID: 0000-0003-4849-8197,

ORCID ID: 0000-0003-4568-586X,

e-mail: Oksanahotiur@gmail.com

Abstract. An important stage in the formation of a future specialist is the independent work of the student, in particular the involvement of the best students in scientific research work, which allows to fully identify the individuality, creativity, readiness for self-realization of students' personality.

Student scientific research work (SRW) is an integral part of the scientific activity of each university in Ukraine and the first stage in the training of scientific personnel, which is usually implemented in the departments (student's scientific circles) and in the scientific structural units of the university (student's scientific society). 
Scientific research is a tool that helps students form a scientific outlook, master the methodology and basic methods of scientific research. SRW promotes accelerated mastery of the specialty and the achievement of high professionalism. Thanks to the research work, the student has the opportunity to develop his creative and scientific thinking, to improve theoretical knowledge, to get acquainted with other young scientists for further cooperation outside the home university.

The main tasks of the scientific research work of students in Ivano-Frankivsk National Medical University are: involvement of talented youth into scientific research, organization of student's participation in competitions of student's scientific works, student's scientific conferences and olympiads.

Scientific work of students of IFNMU is carried out according to the well-known scheme of scientific analysis. The students' research is carried out by scientific and pedagogical staff of the University. Their main task is to assist the student in the process of mastering the basics of scientific search, providing advice and monitoring the implementation of work in all its stages. In the course of research and development, the supervisor helps to select a topic, formulate the purpose and objectives, recommend the most important literature and sources on the subject of work, evaluate the content of the text in its individual components and in general, recommend making changes and refining certain parts of the work.
The scientific-practical conferences at which the students report, starting from the name itself, contain not only and not so much theoretical scientific reports as discussing ways of solving practical problems. Very often, they are held outside the universities, in the territories of medical institutions with which the university maintains relations.

The system of research work is an important component of professional training of the future specialist. It should be aimed at forming the personality of a health care worker who, using the acquired in higher education design (ability to plan any type of work), adaptation (ability to apply this plan in specific conditions), organizational, motivational, communicative, cognitive skills, thus will increase its competitiveness in the labor market.

Conclusion. Therefore, student research work at a medical university is an integral part of the educational activity. It is aimed at integrating scientific, educational and production work in the higher education system and is an integral part of the professional competence and competitiveness of the future graduate in the labor market.

Keywords: scientific research work, student's scientific society.

Стаття надійшла в редакцію 11.09.2019 р. 